\begin{tabular}{c}
\hline Review of \\
ECONOMICS \\
and \\
INSTITUTIONS
\end{tabular}

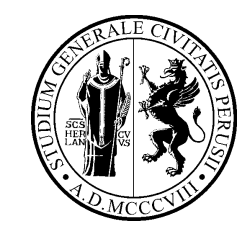

www.rei.unipg.it

\title{
The Role of Institutions in Growth and Development
}

\author{
Daron Acemoglu \\ Massachusetts Institute of Technology
}

\author{
James Robinson \\ Harvard University and Weatherhead \\ Center for International Affairs
}

\begin{abstract}
In this paper we argue that the main determinant of differences in prosperity across countries are differences in economic institutions. To solve the problem of development will entail reforming these institutions. Unfortunately, this is difficult because economic institutions are collective choices that are the outcome of a political process. The economic institutions of a society depend on the nature of political institutions and the distribution of political power in society. As yet, we only have a highly preliminary understanding of the factors that lead a society into a political equilibrium which supports good economic institutions. However, it is clear that it is the political nature of an institutional equilibrium that makes it very difficult to reform economic institutions. We illustrate this with a series of pitfalls of institutional reforms. Our analysis reveals challenges for those who would wish to solve the problem of development and poverty. That such challenges exist is hardly surprising and we believe that the main reason for such challenges is the forces we have outlined in this paper. Better development policy will only come when we recognize this and understand these forces better. Nevertheless, some countries do undergo political transitions, reform their institutions, and move onto more successful paths of economic development. We also can learn a lot from these success stories.
\end{abstract}

JEL classification: 010, P10, P17

Keywords: economic growth, development, institutions and political economy

This paper was previously published as Commission on Growth and Development Working Paper, $n$. 10 (2008). The Review of Economics and Institutions is grateful to the International Bank for Reconstruction and Development, The World Bank, for having authorized its reproduction here.

${ }^{\square}$ Corresponding author. Address: MIT, Department of Economics, 50 Memorial Drive Building E52, Room 380B, Cambridge MA 02142-1347. (Phone: 001-617-2531927, Fax: 001617-2531330, Email: daron@mit.edu)

\section{Recommended Citation}

Acemoglu, D., Robinson,J. (2010). The Role of Institutions in Growth and Development. Review of Economics and Institutions, 1 (2), Article 1. doi:10.5202/rei.v1i2.1.

Retrieved from http://www.rei.unipg.it/rei/article/view/14

Copyright $\odot 2010$ University of Perugia Electronic Press. All rights reserved 


\section{Introduction}

Arguably the most important questions in social science concern the causes of cross-country differences in economic development and economic growth. Why are some countries much poorer than others? Why do some countries achieve economic growth while others stagnate? And to the extent that we can develop some answers to these questions, and the next ones: what can be done in order to induce economic growth and improve the living standards in a society?

Economists have long recognized that output per capita in a society is intimately related to the amount of human capital, physical capital, and technology that workers and firms in that country have access to. Similarly, economic growth is related to the ability of a society to increase its human capital, physical capital, and improve its technology. In this context, technology is construed broadly; technological differences refer not only to differences in techniques available to the firms, but also to differences in the organization of production, implying that some countries will be able to use their resources more efficiently. Nevertheless, differences in human capital, physical capital, and technology are only proximate causes in the sense that they pose the next question of why some countries have less human capital, physical capital, and technology and make worse use of their factors and opportunities. To develop more satisfactory answers to questions of why some countries are much richer than others and why some countries grow much faster than others, we need to look for potential fundamental causes, which may be underlying these proximate differences across countries. Only by understanding these fundamental causes we can develop a framework for making policy recommendations that go beyond platitudes (such as "improve your technology") and also minimize the risk of unintended negative consequences.

In this essay, we will argue that institutions, also very broadly construed, are the fundamental cause of economic growth and development differences across countries and that it is possible to develop a coherent framework for understanding why and how institutions differ across countries, and how they change. We will also argue that our state of knowledge does not yet enable us to make specific statements about how institutions can be improved (in order to promote further economic growth). Nevertheless, we can use this framework in several ways. One is to illustrate the potential pitfalls of institutional reforms. Though this in itself is not a solution to the problem of development, avoiding such pitfalls may be valuable enough to start with. We can also use the framework to structure our understanding of cases of economic success. Though such an 
ex post understanding is not a substitute for policy, it is the first step towards the goal of knowing how to reform institutions.

\section{What Are Institutions?}

Douglass North (1990, p. 3) offers the following definition: “Institutions are the rules of the game in a society or, more formally, are the humanly devised constraints that shape human interaction." Three important features of institutions are apparent in this definition: (1) that they are "humanly devised," which contrasts with other potential fundamental causes, like geographic factors, which are outside human control; (2) that they are "the rules of the game" setting "constraints" on human behavior; (3) that their major effect will be through incentives (see also North, 1981).

The notion that incentives matter is second nature to economists, and institutions, if they are a key determinant of incentives, should have a major effect on economic outcomes, including economic development, growth, inequality, and poverty. But do they? Are institutions key determinants of economic outcomes or secondary arrangements that respond to other, perhaps geographic or cultural, determinants of human and economic interactions?

Much empirical research attempts to answer this question. Before discussing some of this research, it is useful to emphasize an important point: ultimately, the aim of the research on institutions is to pinpoint specific institutional characteristics that are responsible for economic outcomes in specific situations (for example, the effect of legal institutions on the types of business contracts). However, the starting point is often the impact of a broader notion of institutions on a variety of economic outcomes. This broader notion, in line with Douglass North's conception, incorporates many aspects of economics and the political and social organization of society. Institutions can differ between societies because of their formal methods of collective decision-making (democracy versus dictatorship) or because of their economic institutions (security of property rights, entry barriers, the set of contracts available to businessmen). They may also differ because a given set of formal institutions are expected to and do function differently; for example, they may differ between two societies that are democratic because the distribution of political power lies with different groups or social classes, or because in one society democracy is expected to collapse while in the other it is consolidated. This broad definition of institutions is both an advantage and a curse. It is an advantage because it enables us to get started with theoretical and empirical investigations of the role of institutions without getting bogged down by taxonomies. It is a curse 
because unless we can follow it up with a better understanding of the role of specific institutions, we have learned only little.

\section{The Impact of Institutions}

There are tremendous cross-country differences in the way that economic and political life is organized. A voluminous literature documents large cross-country differences in economic institutions, and a strong correlation between these institutions and economic performance. Knack and Keefer (1995), for instance, looked at measures of property rights enforcement compiled by international business organizations, Mauro (1995) looked at measures of corruption, and Djankov et al. (2002) compiled measures of entry barriers across countries. Many other studies look at variation in educational institutions and the corresponding differences in human capital. All of these authors find substantial differences in these measures of economic institutions, and significant correlation between these measures and various indicators of economic performance. For example, Djankov et al. (2002) found that, while the total cost of opening a medium-size business in the United States was less than 0.02 percent of GDP per capita in 1999, the same cost was 2.7 percent of GDP per capita in Nigeria, 1.16 percent in Kenya, 0.91 percent in Ecuador, and 4.95 percent in the Dominican Republic. These entry barriers are highly correlated with various economic outcomes, including the rate of economic growth and the level of development.

Nevertheless, this type of correlation does not establish that the countries with worse institutions are poor because of their institutions. After all, the United States differs from Nigeria, Kenya, and the Dominican Republic in its social, geographic, cultural, and economic fundamentals, so these may be the source of their poor economic performance. In fact, these differences may be the source of institutional differences themselves. Consequently, evidence based on correlation does not establish whether institutions are important determinants of economic outcomes.

To make further progress, one needs to isolate a source of exogenous differences in institutions, so that we approximate a situation in which a number of otherwise-identical societies end up with different sets of institutions. European colonization of the rest of the world provides a potential laboratory to investigate these issues. From the late fifteenth century, Europeans dominated and colonized much of the rest of the globe. Together with European dominance came the imposition of very different institutions and social power structures in different parts of the world. 
Acemoglu et al. (2001) document that in a large number of colonies, especially those in Africa, Central America, the Caribbean, and South Asia, European powers set up "extractive states." These institutions (again broadly construed) did not introduce much protection for private property, nor did they provide checks and balances against the government. The explicit aim of the European in these colonies was extraction of resources, in one form or another. This colonization strategy and the associated institutions contrast with the institutions Europeans set up in other colonies, especially in colonies where they settled in large numbers, for example, the United States, Canada, Australia, and New Zealand. In these colonies the emphasis was on the enforcement of property rights for a broad cross section of the society, especially smallholders, merchants, and entrepreneurs. The term "broad cross section" is emphasized here, since even in the societies with the worst institutions, the property rights of the elite are often secure, but the vast majority of the population enjoys no such rights and faces significant barriers preventing their participation in many economic activities. Although investments by the elite can generate economic growth for limited periods, for sustained growth property rights for a broad cross section seem to be crucial (Acemoglu, 2008).

A crucial determinant of whether Europeans chose the path of extractive institutions was whether they settled in large numbers. In colonies where Europeans settled, the institutions were being developed for their own future benefits. In colonies where Europeans did not settle, their objective was to set up a highly centralized state apparatus, and other associated institutions, to oppress the native population and facilitate the extraction of resources in the short run. Based on this idea, Acemoglu, Johnson, and Robinson (2001) suggest that in places where the disease environments made it easy for Europeans to settle, the path of institutional development should have been different from areas where Europeans faced high mortality rates.

In practice, during the time of colonization, Europeans faced widely different mortality rates in colonies because of differences in the prevalence of malaria and yellow fever. These therefore provide a possible candidate for a source of exogenous variation in institutions. These mortality rates should not influence output today directly, but by affecting the settlement patterns of Europeans, they may have had a first-order effect on institutional development. Consequently, these potential settler mortality rates can be used as an instrument for broad institutional differences across countries in an instrumental-variables estimation strategy.

The key requirement for an instrument is that it should have no direct effect on the outcome of interest (other than its effect via the endogenous 
regressor). There are a number of channels through which potential settler mortality could influence current economic outcomes or may be correlated with other factors influencing these outcomes. Nevertheless, there are also good reasons for why, as a first approximation, these mortality rates should not have a direct effect. Malaria and yellow fever were fatal to Europeans who had no immunity, thus having a major effect on settlement patterns, but they had much more limited effects on natives who, over centuries, had developed various types of immunities. The exclusion restriction is also supported by the death rates of native populations, which appear to be similar between areas with very different mortality rates for Europeans (see, for example, Curtin, 1964).

The data also show that there were major differences in the institutional development of the high-mortality and low-mortality colonies. Moreover, consistent with the key idea in Acemoglu et al. (2001), various measures of broad institutions, for example, measures of protection against expropriation, are highly correlated with the death rates Europeans faced more than 100 years ago and with early European settlement patterns. They also show that these institutional differences induced by mortality rates and European settlement patterns have a major (and robust) effect on income per capita. For example, the estimates imply that improving Nigeria's institutions to the level of those in Chile could, in the long run, lead to as much as a 7-fold increase in Nigeria's income. This evidence suggests that once we focus on potentially exogenous sources of variation, the data points to a large effect of broad institutional differences on economic development.

Naturally, mortality rates faced by Europeans were not the only determinant of Europeans' colonization strategies. Acemoglu et al. (2002) focus on another important aspect, how densely different regions were settled before colonization. They document that in more densely settled areas, Europeans were more likely to introduce extractive institutions because it was more profitable for them to exploit the indigenous population, either by having them work in plantations and mines, or by maintaining the existing system and collecting taxes and tributes. This suggests another source of variation in institutions that may have persisted to the present, and Acemoglu et al. (2002) show similar large effects from this source of variation.

Another example that illustrates the consequences of difference in institutions is the contrast between the Democratic People's Republic of Korea and the Republic of Korea. The geopolitical balance between the Soviet Union and the United States following the World War II led to separation along the 38th parallel. The Democratic People's Republic of Korea, under the dictatorship of Kim Il Sung, adopted a very centralized command economy with little role for private property. In the meantime, 
the Republic of Korea relied on a capitalist organization of the economy, with private ownership of the means of production, and legal protection for a range of producers, especially those under the umbrella of the chaebols, the large family conglomerates that dominated the Republic of Korea's economy. Although not democratic during its early phases, the Republic of Korea's state was generally supportive of rapid development and is often credited with facilitating, or even encouraging, investment and rapid growth.

Under these two highly contrasting regimes, the economies of the Democratic People's Republic of Korea and the Republic of Korea diverged. While the Republic of Korea has grown rapidly under capitalist institutions and policies, the Democratic People's Republic of Korea has experienced minimal growth since 1950, under communist institutions and policies.

Overall, a variety of evidence paints a picture in which broad institutional differences across countries have had a major influence on their economic development. This evidence suggests that to understand why some countries are poor we should understand why their institutions are dysfunctional. But this is only part of a first step in the journey towards an answer. The next question is even harder: if institutions have such a large effect on economic riches, why do some societies choose, end up with, and maintain these dysfunctional institutions?

\section{Modeling Institutional Differences}

As a first step in modeling institutions, let us consider the relationship between three institutional characteristics: (1) economic institutions; (2) political power; (3) political institutions.

As already mentioned above, economic institutions matter for economic growth because they shape the incentives of key economic actors in society. In particular, they influence investments in physical and human capital and technology and the organization of production. Economic institutions not only determine the aggregate economic growth potential of the economy, but also the distribution of resources in the society, and herein lies part of the problem: different institutions will not only be associated with different degrees of efficiency and potential for economic growth, but also with different distribution of the gains across different individuals and social groups.

How are economic institutions determined? Although various factors play a role here, including history and chance, at the end of the day, economic institutions are collective choices of the society. And because of their influence on the distribution of economic gains, not all individuals 
and groups typically prefer the same set of economic institutions. This leads to a conflict of interest among various groups and individuals over the choice of economic institutions, and the political power of the different groups will be the deciding factor.

The distribution of political power in society is also endogenous. To make more progress here, let us distinguish between two components of political power - de jure and de facto political power (see Acemoglu and Robinson, 2006a). De jure political power refers to power that originates from the political institutions in society. Political institutions, similar to economic institutions, determine the constraints on and the incentives of the key actors, but this time in the political sphere. Examples of political institutions include the form of government, for example, democracy versus dictatorship or autocracy, and the extent of constraints on politicians and political elites.

A group of individuals, even if they are not allocated power by political institutions, may possess political power; for example, they can revolt, use arms, hire mercenaries, co-opt the military, or undertake protests in order to impose their wishes on society. This type of de facto political power originates from both the ability of the group in question to solve its collective action problem and from the economic resources available to the group (which determines their capacity to use force against other groups).

This discussion highlights that we can think of political institutions and the distribution of economic resources in society as two state variables, affecting how political power will be distributed and how economic institutions will be chosen. An important notion is that of persistence; the distribution of resources and political institutions are relatively slowchanging and persistent. Since, like economic institutions, political institutions are collective choices, the distribution of political power in society is the key determinant of their evolution. This creates a central mechanism of persistence: political institutions allocate de jure political power, and those who hold political power influence the evolution of political institutions, and they will generally opt to maintain the political institutions that give them political power. A second mechanism of persistence comes from the distribution of resources: when a particular group is rich relative to others, this will increase its de facto political power and enable it to push for economic and political institutions favourable to its interests, reproducing the initial disparity. We shall see later that these ideas are powerful in developing ideas about why reform is so difficult. Reform comes with pitfalls because either de facto or de jure power may persist even if other things change.

Despite these tendencies for persistence, the framework also emphasizes the potential for change. In particular, "shocks" to the balance of de facto political power, including changes in technologies and the 
international environment, have the potential to generate major changes in political institutions, and consequently in economic institutions and economic growth.

Acemoglu, Johnson, and Robinson (2005b) summarized this framework with the following schematic representation:

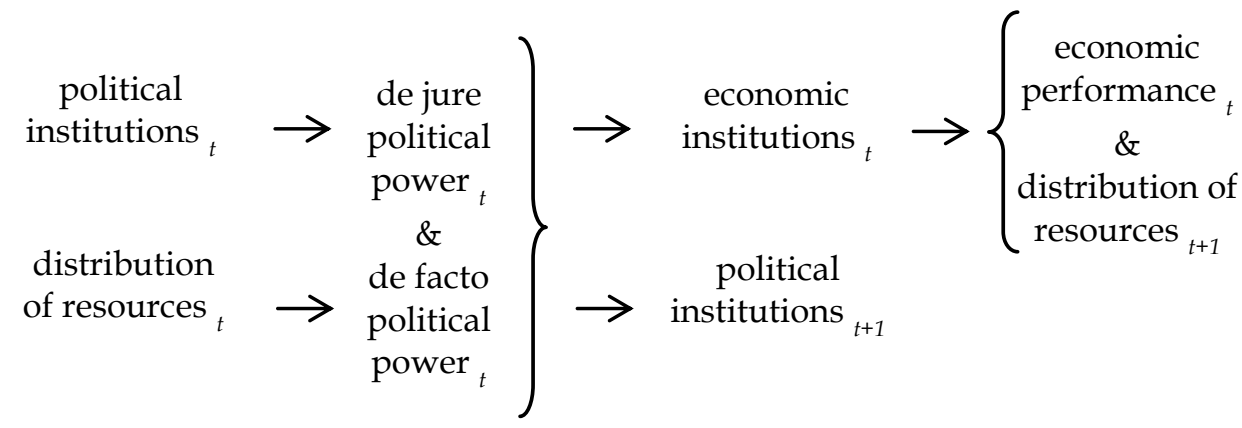

\section{A Simple Historical Example}

As a brief example, consider the development of property rights in Europe during the late Middle Ages and Early Modern period. Lack of property rights for landowners, merchants, and proto-industrialists was detrimental to economic growth during this epoch. Since political institutions at the time placed political power in the hands of kings and various types of hereditary monarchies, such rights were largely decided by these monarchs. The monarchs often used their powers to expropriate producers, impose arbitrary taxation, renege on their debts, and allocate the productive resources of society to their allies in return for economic benefits or political support. Consequently, economic institutions during the Middle Ages provided little incentive to invest in land, physical or human capital, or technology, and failed to foster economic growth. These economic institutions also ensured that the monarchs controlled a large fraction of the economic resources in society, solidifying their political power, and ensuring the continuation of the political regime.

The seventeenth century, however, witnessed major changes in the economic and political institutions that paved the way for the development of property rights and limits on monarchs' power, especially in England after the Civil War of 1642 and the Glorious Revolution of 1688, and in the Netherlands after the Dutch Revolt against the Hapsburgs. How did these major institutional changes take place? In England until the sixteenth century the king also possessed a substantial amount of de facto political power, and leaving aside civil wars related to royal succession, no other social group could amass sufficient de facto political power to challenge the king. But changes in the English land market (Tawney, 1941) and the expansion of Atlantic trade in the sixteenth 
and seventeenth centuries (Acemoglu et al., 2005a) gradually increased the economic fortunes, and consequently the de facto power of landowners and merchants opposed to the absolutist tendencies of the kings.

By the seventeenth century, the growing prosperity of the merchants and the gentry, based both on internal and overseas (especially Atlantic) trade, enabled them to field military forces capable of defeating the king. This de facto power overcame the Stuart monarchs in the Civil War and Glorious Revolution, and led to a change in political institutions that stripped the king of much of his previous power over policy. These changes in the distribution of political power led to major changes in economic institutions, strengthening the property rights of both land and capital owners and spurring a process of financial and commercial expansion. The consequence was rapid economic growth, culminating in the Industrial Revolution, and a very different distribution of economic resources from that in the late Middle Ages.

This discussion poses, and also gives clues about the answers to, two crucial questions. First, why do the groups with conflicting interests not agree on the set of economic institutions that maximize aggregate growth? Second, why do groups with political power want to change political institutions in their favor? In the context of the example above, why did the gentry and merchants use their de facto political power to change political institutions rather than simply implement the policies they wanted? The issue of commitment is at the root of the answers to both questions.

An agreement on the efficient set of institutions is often not forthcoming because of the complementarity between economic and political institutions and because groups with political power cannot commit to not using their power to change the distribution of resources in their favor. For example, economic institutions that increased the security of property rights for land and capital owners during the Middle Ages would not have been credible as long as the monarch monopolized political power. He could promise to respect property rights, but then at some point, renege on his promise, as exemplified by the numerous financial defaults by medieval kings. Credible secure property rights necessitated a reduction in the political power of the monarch. Although these more secure property rights would foster economic growth, they were not appealing to the monarchs, who would lose their rents from predation and expropriation as well as various other privileges associated with their monopoly of political power. This is why the institutional changes in England as a result of the Glorious Revolution were not simply conceded by the Stuart kings. James II had to be deposed for the changes to take place. 
The reason why political power is often used to change political institutions is related. In a dynamic world, individuals care not only about economic outcomes today but also in the future. In the example above, the gentry and merchants were interested in their profits and therefore in the security of their property rights, not only in the present but also in the future. Therefore, they would have liked to use their (de facto) political power to secure benefits in the future as well as the present. However, commitment to future allocations (or economic institutions) is in general not possible because decisions in the future are made by those who hold political power at the time. If the gentry and merchants would have been sure to maintain their de facto political power, this would not have been a problem. However, de facto political power is often transient, for example because the collective action problems that are solved to amass this power are likely to resurface in the future, or other groups, especially those controlling de jure power, can become stronger in the future. Therefore, any change in policies and economic institutions that relies purely on de facto political power is likely to be reversed in the future. In addition, many revolutions are followed by conflict within the revolutionaries. Recognizing this, the English gentry and merchants strove not just to change economic institutions in their favor following their victories against the Stuart monarchy, but also to alter political institutions and the future allocation of de jure power. Using political power to change political institutions then emerges as a useful strategy to make gains more durable. Consequently, political institutions and changes in political institutions are important as ways of manipulating future political power, and thus indirectly shaping future, as well as present, economic institutions and outcomes.

\section{Pitfalls of Reform}

The framework we have sketched above is useful in delineating a range of dysfunctional political equilibria and consequent economic institutions. We have also emphasized how it is important to understand the political forces and institutions that maintain these dysfunctional economic institutions in place and are often mutually self-reinforcing (complementary) with these economic institutions. Nevertheless, at present we do not have a satisfactory understanding of the circumstances under which dysfunctional political equilibria arise and sustain themselves. A natural idea would be to focus on specific political institutions such as democracy. Yet we know that democracy per se is not necessarily associated with better development outcomes and we all know the famous examples of "developmental dictatorships" such as in the 
Republic of Korea or Taiwan, China. However, as yet, we do not understand why some dictatorships are developmental and others not or why, for instance, there has never been a developmental dictatorship in sub-Saharan Africa or Latin America.

Though we cannot yet say under what circumstances political equilibria that lead to economic growth will arise, we can illustrate the power of the ideas we have developed by examining the issue of institutional reform. If economic institutions do not create the right incentives in society then a natural approach is to directly try to reform economic institutions. If security of property rights is the problem under kleptocracies, why not introduce (or force dictators to introduce) more secure property rights? The potential problems facing such an approach highlight the first set of pitfalls of institutional reform. Our framework emphasizes that one should not try to understand or manipulate economic institutions without thinking about the political forces that created or sustain them. Although blatant disregard for property rights is a powerful distortionary force in kleptocratic societies, it is not the only instrument available to a dictator who wants to extract resources from the rest of the society.

The comparison of Ghana in the 1960s and 1970s and current Zimbabwe nicely illustrates these ideas. In Zimbabwe the mass expropriation and redistribution of agricultural land has led to a collapse in the economy (GDP per capita has apparently fallen by around 50 percent since the introduction of the Fast-Track land reform policy in 2000). In Ghana agricultural policies were also motivated by the desire to redistribute incomes (Bates, 1981), but the property rights of rural producers were never challenged. Instead, a succession of governments used monopsony marketing boards to set very low prices for crops such as cocoa. The instruments were very different but the motivation and economic effects were similar.

This reasoning suggests that direct institutional reform in itself is unlikely to be effective and that instead it might be more useful to focus on understanding and reforming the forces that keep bad institutions in place. It is therefore important to focus on political institutions and the distribution of political power as well as the nature of economic institutions in thinking about potential institutional reform or institution building. This raises the second potential pitfall of institutional reform; although we have recognized the importance of political institutions, we are still at the beginning of understanding the complex relationship between political institutions and the political equilibrium. Sometimes changing political institutions may be insufficient, or even counterproductive, in leading to better economic outcomes. Once again the use of a theoretical framework in thinking about these issues is useful both for academic research and in generating better policy advice. 
The pitfalls of institutional reform are related to the fact that patterns of relative economic performance are very persistent. Indeed, our framework emphasized persistence. This is not to say that change does not occur: it does, and some countries manage to dramatically change their position in the world income distribution. However, it is a striking fact in the Americas, to take one example, that the rank order of countries in terms of income per capita has been basically unchanged at least since the middle of the nineteenth century. This suggests that it is difficult to change institutions and there are powerful forces at work reinforcing the status quo. Examining the pitfalls of reform is one way of approaching this issue. We then move to examining successful change.

We begin our discussion by focusing at more length on whether reforming specific economic institutions is likely to be effective. We argue that such reforms may not work if they do not change the political equilibrium. We then examine if these pitfalls of reform can be solved by reforming political institutions (thus altering the distribution of de jure power in society). We argue that this may not work either, because de facto power may persist and may override the effects of reforms to political institutions. From this it might seem to follow that a successful reform necessitates changes in both de jure and de facto power. We show that simultaneously changing both may not achieve real reform either, because the political equilibrium may be path dependent

\subsection{Persistence of Power and Incentives: the See-saw Effect}

Many dysfunctional economic institutions are supported by a system of specific laws and regulations that relate to economic institutions. This is true for the labor repressive agricultural societies of nineteenth century Russia and Eastern Europe (Acemoglu and Robinson, 2006b) or twentiethcentury Guatemala and El Salvador, where the legal system kept workers in semi-servile status and blocked their mobility. It is also true of highly oligarchic societies with very concentrated industrial structures, such as modern Mexico, where specific barriers to entry block competition. An obvious idea might be to change the laws and regulations. For example, if Latin American countries grew slowly after the Second World War because they levied high tariffs on imports, then irrespective to what forces led these tariffs to be put in place, removing them ought to stimulate growth. This was the sort of reasoning that led to the famous Washington consensus.

The first pitfall of institutional reform is that directly reforming specific economic institutions (such as the trade regime) may not be sufficient, and may even backfire. The reason why reforms of specific economic institutions may be ineffective is that there are many different ways and a multitude of instruments to achieve a specific goal. Taking away one 
instrument without altering the balance of power in society or the basic political equilibrium can simply lead to the replacement of one instrument by another. This phenomenon was dubbed the see-saw effect by Acemoglu et al. (2003).

\subsubsection{Case Study: Reform and the New Clientelism in Latin America}

Prominent examples of reforms were those imposed on Latin American countries following the debt crisis of the 1980s. As part of packages to repay debt, Latin American countries abandoned many aspects of the economic institutions that had been prevalent since the 1930s and 1940s. Policy reforms that took place in the late 1980s and 1990s included deregulation of the trade regime and severe cuts in tariffs, privatization, and financial deregulation. Though this had been done earlier in Chile and attempted by the military regime in Argentina after 1976, this was now done wholesale in most Latin American countries. Even though there was an economic crisis, the acceptance of these policy reforms by such institutions as the Peronist party in Argentina appears to be quite strange. Enduring crises and many rounds of policy reform have not induced many African countries to reform. One difference, of course, is that Latin American countries are more democratic than African ones, making it more difficult to maintain the status quo in the face of economic collapse. Another important difference is that Latin American politicians realized that the policies of neoliberalism could be manipulated to fulfil clientelistic ends. As Roberts (1995, p. 114) convincingly argues in his analysis of the reforms of Fujimori, "the Peruvian case demonstrates that it may be possible to craft populist formulas that complement neoliberalism." For example, privatization could be organized to redistribute rents by reducing competition and giving privatized assets as favors to political supporters (see Gibson, 1997; Roberts and Arce, 1998; Weyland, 1998 and 2000). There were of course differences: for example, in Argentina the Peronist party distanced itself from its traditional supporters in the labor movement. But such a strategy was feasible because the political power of the labor movement had been severely damaged by repression under the military. The Peronist party was able to reinvent itself (Levitsky, 2003) and carry on with clientelism as usual.

The see-saw effect operates here in the following sense: to win power in Argentina, for example, the Peronist party traditionally engaged in redistribution of incomes and rents. The instruments it used to do this included rationing of foreign exchange, or the distribution of rents via industrial licenses. The policy reforms of the 1990s meant that these old instruments could not be used. For example, the currency board took away the ability of rationing access to foreign exchange. But other instruments were available to achieve the same ends: for example, the 
labor movements were compensated for some deregulation by being able to benefit from privatization. Despite the crises on the 1980s, some changes in the distribution of political power in Argentine society (the unions were weaker), and changes in the feasible instruments through which to pursue clientelism, the political incentive environment was remarkably stable over time and as a consequence there was little improvement in the economic incentive environment in Argentina.

\subsubsection{Case Study: the Structural Adjustment of Politics in Africa}

Another important example of the see-saw effect comes from the politics of structural adjustment in Africa. The attempt to induce African countries to implement institutional reforms such as reducing distortions was not a success (van der Walle, 1993 and 2000), mostly for the reason that international financial institutions did not take into account the political rationale for the inefficient policies they were trying to reform. The most dramatic example of this is discussed by Herbst (1990) and Reno (1998). They argued that attempts by IFIs to induce downsizing of the public sector, for example by closing down unprofitable parastatals, had played an important role in creating civil war in Sierra Leone and Liberia. Regimes in both countries had used public sector employment as a method of redistributing rents to opponents or potential opponents of the regime and buying political support. Once these options had been taken away by structural adjustment, more opposition to the regimes emerged and incumbents switched from using carrots to using sticks. In this story, policy reform induced a switch from one inefficient instrument, patronage through public sector employment, to an even more inefficient one, repression. This is the see-saw effect in action.

\subsubsection{General Lessons}

Making or imposing specific institutional reforms may have little impact on the general structure of economic institutions or performance if they leave untouched the underlying political equilibrium. Of course, as the framework above emphasized, political power will to some extent reflect economic institutions so it is possible that a change in economic institutions may induce a change in de facto power and ultimately in the broader political equilibrium. Nevertheless, as the above examples make clear, this is far from certain. A piecemeal approach may be dangerous. Often we see the symptoms, but they are precisely the symptoms of deeper causes. Dealing with the symptoms other than causes may backfire.

Despite all of the Washington consensus reforms that took place in Argentina, for example, there was little change in the way politics worked. The political genius of Menem and the Peronist party after 1989 was to 
recognize that the policies of the Washington consensus could be bent to function as "politics as usual." In consequence there was little change in the underlying political equilibrium though the instruments which the Peronists used after 1989 were different. This perspective is of course very different from that which claims that the Washington consensus reformed failed (Rodrik, 2006). Our view is not that they failed, but that for them to succeed it would be necessary to induce a change in the political equilibrium in Argentina. Though it is possible that such reforms could change the political equilibrium, it did not happen.

The points are related to those made by Stigler (1971 and 1982) and Coate and Morris (2005) in their discussion of the political economy of income redistribution. Stigler pointed out that it was political incentives that led income redistribution to take a socially inefficient form. For instance, although it might be better to redistribute to farmers by giving them lump-sum transfers, subsidizing farm output might be more attractive politically because it was not perceived as income redistribution by other voters (see Coate and Morris, 1995, for a formalization of this idea). This being the case, Coate and Morris (2005) noted that policy reform that aimed at banning the use of particular inefficient instruments might be counterproductive because rational politicians would already be using the least-cost way of redistributing, given the political constraints and incentives they faced.

\subsection{Persistence of De Facto Power}

The last section illustrated that reforming specific economic institutions without perturbing the underlying political equilibrium may not lead to improved economic institutions or performance. Moreover, we shall now argue that even reforming de jure power (for instance enfranchising former slaves) or introducing democracy may not be sufficient to induce broader institutional change. The reason why changes in de jure power may not be sufficient to trigger a change in the political equilibrium is that the political and economic system is kept in place by a combination of de jure and de facto political power. An external or internal impetus to change de jure institutions may still leave the sources of de facto power intact, and groups that have lost their de jure power may use their de facto power in order to recreate a system similar to the one that has departed (Acemoglu and Robinson, 2006c and 2008). The new system may be as inefficient as the old one.

This is not to argue that reform of de jure institutions is not possible or that it is irrelevant. For example, democratization in many European societies in the nineteenth century appears to have significantly changed economic institutions, for example leading to sustained expansions of 
educational systems (Acemoglu and Robinson, 2000; Lindert, 2004). Nevertheless, this section emphasizes that such reforms come with pitfalls.

\subsubsection{Case Study: the Persistence of the Southern Equilibrium}

\footnotetext{
"De landlord is landlord, de politician is landlord, de judge is landlord, de shurf is landlord, ever'body is landlord, en we ain' got nothin."

Testimony of a Mississippi sharecropper to an official of the Agricultural Adjustment Administration in 1936 (Schulman, 1994, p. 16)
}

An important example that illustrates our thesis is the continuation of the economic system based on labor repression, plantation, and low-wage uneducated labor in the U.S. South before and after the significant changes in political institutions brought about by the Civil War. Most obviously these changes in de jure power included the enfranchisement of the freed slaves.

Before the Civil War, the South was significantly poorer than the U.S. average income at about 70 percent of GDP per capita. The South lacked industry (Bateman and Weiss, 1981; Wright, 1986, Table 2.4, p. 27) and in 1860 the total manufacturing output of the South was less than that of either Pennsylvania, New York, or Massachusetts (Cobb, 1984, p. 6). The South had very low rates of urbanization (around 9 percent as opposed to 35 percent in the Northeast) and relatively little investment in infrastructure. For example, the density of railroads (miles of track divided by land area) was three times higher in the North than in Southern states. The situation with respect to canal mileage was similar (Wright, 1986, Table 2.1, p. 21). Perhaps more important, especially in the context of the potential for future economic growth and industrialization, the South was not even innovative for the sectors in which it specialized.

The relatively backwardness of the South was because of the plantation economy and slavery. Wright (1986) argues that because slaves were a mobile asset, there was no incentive for planter interests to support investment in public goods such as infrastructure, and so manufacturing could not develop. Bateman and Weiss (1981) show that Southern planters did not invest in industry, even though the rate of return was superior to that in agriculture. A plausible explanation for the lack of innovation is that slavery limited the possibilities for productive investment. Slaves were forbidden to own property or to become educated in most Southern states, presumably because this made them easier to control. But this pattern of labor repression also condemned plantations to low-skilled labor forces and possibly removed the incentives of planters to innovate.

In the aftermath of the Civil War, the income per capita of the South fell to about 50 percent of the U.S. average. If the organization of the slave economy had been the reason why the South had been relatively 
backward in 1865, one might have imagined that the abolition of slavery in 1865 would have removed this blockage to Southern prosperity. The evidence and historical interpretations show that the abolition of slavery had a surprisingly small effect on the Southern economy. Though planters initially tried and failed to reintroduce the gang-labor system with the freed slaves, out of the ashes of the Civil War emerged a low-wage, laborintensive economy based on labor repression. Cut off from the rest of the United States, income per capita remained at about half the national average until the 1940s when it finally began slowly to converge. Just as before the Civil War, there was systematic underinvestment in education (Margo, 1990). The main incentive for this seems to have been to impede migration (see Wright, 1986, p. 79). In 1900 all but two of the non-Southern states had enacted compulsory schooling laws, while none had such laws in the South except Kentucky (Woodward, 1951, p. 399). Though industrial development did begin more systematically after 1865, Cobb (1984, p. 17) notes:

The industries that grew most rapidly in the post-Reconstruction decades were typical of an underdeveloped economy in that they utilized both cheap labor and abundant raw materials ... such industries hardly promised to elevate the region to economic parity with the rest of the nation.

So why did the economic system of the South change so little following the Civil War, especially given the significant changes in political institutions? At first, this persistence of economic institutions appears at odds with the significant changes in the distribution of de jure power that took place after the Civil War, for example, with the enfranchisement of the freed slaves, and the repeal of the Missouri Compromise, which had previously cemented the political power of the South in the federal government.

We believe the answer is related to the exercise of de facto political power by the Southern landed elites to compensate for the loss of their de jure political power. Consistent with our approach, there was considerable persistence in the identity and power of the political elites. For example, Wiener (1978) studied the persistence of the planter elite in five counties of the black belt of western Alabama. Tracking families from the U.S. census and considering those with at least US\$10,000 of real estate, he found that (p. 9) "of the 236 members of the planter elite in 1850, 101 remained in the elite in 1870." Interestingly, this rate of persistence was very similar to that experienced in the antebellum period: "of the 236 wealthiest planters families of 1850, only 110 remained in the elite a decade later" (p. 9). Nevertheless, "of the 25 planters with the largest landholdings in 1870, 18 (72 percent) had been in the elite families in 1860; 16 had been in the 1850 elite group." 
After the end of the Civil War, more or less the same group of planter elites controlled the land and used various instruments to re-exert their control over the labor force. Though the specific economic institution of slavery did not persist, the evidence shows a clear line of persistence in the economic system of the South based on plantation-type agriculture with cheap labor. This economic system was maintained through a variety of channels, including both control of local politics and exercise of potentially violent de facto power. As a consequence, in the words of W.E.B. Du Bois (1903, p. 88), the South became "simply an armed camp for intimidating black folk."

The planter elite successfully staffed or co-opted the members of the Freedmen's Bureau, whose remit was to supervise the freed slaves. In 1865 the state legislature of Alabama passed the Black Code, an important landmark towards the repression of black labor. Wiener (1978, p. 58) describes this as follows: "The Black Code of Alabama included two key laws intended to assure the planters a reliable supply of labor - a vagrancy law, and a law against the 'enticement' of laborers." These laws were designed to impede labor mobility and reduce competition in the labor market.

In addition to modelling the legal system in their favor, "Planters used Klan terror to keep blacks from leaving the plantation regions, to get them to work, and keep them at work, in the cotton field" (Wiener, 1978, p. 62). In his seminal study of the politics of the South after World War II, Key (1949, p. 9) sums up the pattern of persistence of the institutions of the South both before and after the Civil War as the "extraordinary achievement of a relatively small minority - the whites of the areas of heavy Negro population."

A key to the persistence of the antebellum system after the Civil War was the continued control over land. For example, in the debate over the redistribution of 40 acres of land to the freedmen (vetoed by President Andrew Johnson in 1865), Congressman George Washington Julian argued (quoted in Wiener, 1978, p. 6):

\footnotetext{
Of what avail would be an act of congress totally abolishing slavery ... if the old agricultural basis of aristocratic power shall remain?
}

A third strategy, again consistent with the emphasis on the de facto political power of the elite in our theoretical analysis, was control of the local political system. Following the Civil War, the period called Reconstruction lasted until 1877. In this period Republican politicians contested power in the South and, with the help of the Union Army, engineered some social changes. Nevertheless, this induced a systematic backlash in the guise of support for the Democratic Party and the so-called 
"Redeemers." In 1877, in the context of a log-roll between President Rutherford Hayes and Southern national politicians, Union soldiers were withdrawn from the South and the region left to its own devices. The period after 1877 then marked the real recrudescence of the antebellum elite. The "redemption" of the South involved the systematic disenfranchisement of the black (and poor white) population through the use of poll taxes and literacy tests (Key, 1949; Kousser, 1974) and the creation of the one-party Democratic regime.

Key (1949, pp. 309-10), in his analysis of the primary elections of the Democratic party, noted the hegemony of southern society's "upper brackets" and the political marginalization of its "lower brackets." He discusses in detail the control of North Carolina's economic oligarchy over politics, noting that (p. 211): “The effectiveness of the oligarchy's control has been achieved through the elevation to office of persons fundamentally in harmony with its viewpoint."

This picture is also confirmed by the analysis of Wright (1986, p. 78), who writes: "Even in the 1930s, southern representatives in Washington did not use their powerful positions to push for new federal projects, hospitals, public works and so on. They didn't, that is, as long as the foundations of the low-wage regional economy persisted."

In addition to disenfranchisement, a whole gamut of segregationist legislation - the so-called Jim Crow laws - was enacted (see Woodward, 1955, for the classic analysis). These laws turned the postbellum South into an effective "apartheid" society where blacks and whites lived different lives. As in South Africa, these laws were aimed at controlling the black population and its labor supply.

Consequently, the South entered the twentieth century as a primarily rural society. "It remained an agrarian society with a backward technology that still employed hand labor and mule power virtually unassisted by mechanical implements" (Ransom and Sutch, 2001, pp. 175176). In 1900, the South's urbanization rate was 13.5 percent, as compared to 60 percent in the Northeast (Cobb, 1984, p. 25).

Ransom and Sutch's (2001, p. 186) assessment of the implications of this economic and political system in the South for economic progress is representative of the consensus view: "Southerners erected an economic system that failed to reward individual initiative on the part of blacks and was therefore ill-suited to their economic advancement. As a result, the inequities originally inherited from slavery persisted. But there was a byproduct of this effort at racial repression, the system tended to cripple all economic growth".

When whites used threats of violence to keep blacks from gaining an education, practicing a trade, or purchasing land, they systematically prevented 
blacks from following the three routes most commonly travelled by other Americans in their quest for self-advancement. With over half the population held in ignorance and forced to work as agricultural laborers, it is no wonder that the South was poor, underdeveloped, and without signs of economic progress. (Ransom and Sutch, 2001, p. 177)

All in all, the Southern equilibrium, based on the exercise of de facto power by the landed elite, plantation agriculture, and low-wage, uneducated labor, persisted well into the twentieth century, and only started to crumble after World War II. Interestingly, it was only after the demise of this Southern equilibrium that the South started its process of rapid convergence to the North.

\subsubsection{Case Study: the Reinvention of the Cambodian People's Party}

In 1978 senior Khmer Rouge cadres, including Heng Samrin, Chea Sim, and Hun Sen, escaped to Vietnam after falling out with Pol Pot. In 1979 they were placed in power in Phnom Penh by the Vietnamese Army and formed the Communist Party of Kampuchea. In the 1980s they tried to implement socialism, but after the Berlin Wall came down Hun Sen and his colleagues renamed their party the Cambodian People's Party (CPP), became democrats, and negotiated an opening of the political system (Hughes, 2003). Though this involved the return of King Norodom Sihanouk from exile and necessitated that Hun Sen share power, his party, the CPP, managed to reinvent itself as a democratic political machine. For instance, in 2002 elections were introduced for commune chiefs, who had previously been appointed. The CPP won 1,591 of 1,621. Primarily via its control of the bureaucracy and military, the CPP wins every election and those who oppose it too strenuously, such as Sam Rainsy, are exiled or arrested. Here despite the change in de jure institutions, the huge de facto power of the CPP means that they can dominate democratic politics through superior organization and resources, heavily aided by threats and intimidation.

\subsubsection{General Lessons}

Just as reforming economic institutions without changing the political equilibrium may not improve the institutional equilibrium, so changing de jure power, while leaving the sources of de facto power intact, may have little impact on economic performance. In the U.S. South, the same economic system based on the repression of cheap labor got reinstituted after Reconstruction. Even though the enfranchisement of the freed slaves meant that there had been a change in de jure power, and after the Civil War blacks exercised this power and voted in large numbers, Southern elites were able to use their de facto power to reassert control over labor 
and eventually by the 1890s disenfranchise the blacks. The persistence of de facto power stemmed from the fact that white elites had kept hold of the land after the Civil War, and because these elites had avoided being killed during the Civil War and still had a huge comparative advantage over blacks in the ability to engage in collective action. Control was exercised via coercion, lynching, the Ku Klux Klan, and other extra-legal methods and eventually institutionalized via control of state legislatures.

In Cambodia, the transition away from socialism after 1989 and the opening of the political system and creation of de jure democracy after 1993 have not been sufficient to change the political equilibrium. The Cambodian People's Party, led by former Khmer Rouge cadres like Hun Sen and Chea Sim, have been able to use their control of the bureaucracy and the army to win elections and have emasculated, co-opted, and sometimes banned the opposition. Though there have been large changes in specific economic institutions, particularly with the move away from socialism to capitalism, and alterations in de jure political institutions, the society continues to be run to the benefit of a small elite who are free to enrich themselves at the expense of the wider society.

The general lesson seems to be that change in institutions, which affects the distribution of de jure political power, needs to be complemented by changes in the sources of de facto political power of the elite and reductions in the benefits that political incumbents have in intensifying their use of de facto political power (for example, use of paramilitaries, bribery, corruption, and so forth).

\subsection{The Iron Law of Oligarchy}

The conclusion from the last section seems to be that to change the political equilibrium there needs to be changes in both de jure and de facto power. For instance, if there is an elite that is structuring institutions to its benefit with adverse aggregate effects, then to engineer a transition to a better equilibrium both their de jure and de facto power must be simultaneously reformed. To take a contemporary example, this would imply that to reform Iraq, it would not be sufficient to simply remove Saddam Hussein and introduce democracy. This is because the Ba'ath Party would still have had terrific de facto power and would be able to capture the new political institutions. To really achieve reform it would be necessary to undermine the de facto power of the Ba'ath Party, something the U.S. government clearly succeeded in doing.

Unfortunately, things are not quite so simple as this. This is because even if de jure and de facto power changes, those who acquire the power in the new political equilibrium may not have the correct incentives either. More importantly, their incentives to use their power and the institutions they find it optimal to create may be fundamentally shaped by the status 
quo they replace - they may be path dependent. If an elite with power is initially structuring economic institutions to extract rents from society, then the very fact that it is doing this may induce a new elite to do likewise. The replacement of one elite by another may therefore do little to improve economic performance. This pitfall is reminiscent of the classic idea in sociology of an iron law of oligarchy going back to the work of Michels (1962), Mosca (1939), and Pareto (1968). This hypothesis states that it is never possible to have real change in society, because when new groups mobilize or are created in the process of socioeconomic change, they simply replace preexisting elites and groups and behave in qualitatively similar ways (see Acemoglu and Robinson, 2007). There seem to be many circumstances in which "iron law" types of behavior may occur and there are quite possibly many mechanisms that can generate behavior like this. We focus on two that appear to be first order. The first is motivated by the experience of Bolivia following the Revolution of 1952. The second is motivated by the experience of Africa, where many countries have experienced sequences of one bad leader after another.

\subsubsection{The Bolivian Revolution and the Iron Law}

Bolivia features centrally in accounts of comparative development in the Americas. It was at the heart of the Inca Empire with a high density of indigenous peoples and during the colonial period economic institutions designed to extract rents - the encomienda, repartamiento, and the Potosi mita (forced labor draft for the silver mines) - were all central. Although the mita was abolished at independence, a highly inegalitarian and authoritarian society persisted. In 1950, for example, 6 percent of landowners owned 92 percent of all lands and the smallest 60 percent of landowners owned 0.2 percent; and the tin mines, which formed the basis of the export economy, were owned by three families. A mere 31 percent of the adult population was literate and only 4 percent of the labor force was employed in industry. Indians still were subject to unpaid pongueaje (personal services) for the landowners whose lands they worked.

The remains of this system were swept away by the Bolivian revolution of 1952, which was masterminded by the MNR (Movimiento Nacionalista Revolucionario), a political party that had formed in urban areas in the 1940 s to contest the power of the traditional elite. Following the Revolution, the MNR formed a government that implemented land reform, expropriated large estates, and redistributed them to the labor force and Indian communities. It also introduced universal suffrage by abolishing literacy requirement on voting and nationalized the mines of the tin barons.

These appear to be huge, radical institutional changes. In particular there was a shift in the distribution of both de jure and de facto power. 
Surely Bolivia was launched on a new path of institutional and economic development. At the very least one would have anticipated a sustained fall in inequality. Unfortunately none of these good outcomes occurred. Following the Revolution, the 1950s saw a failed attempt by the MNR to create a one-party state and in the process they rebuilt the military that had been disarmed in 1952. They were also able to use clientelism to gain the support of the indigenous majority. Indeed, there are striking comparisons between the traditional clientelism that had existed before 1952 and that which emerged during the regime of the MNR afterwards. In a seminal study, Heath (1972) showed that although the identity of the patrons were different and the instruments of clientelism had changed following the institutional changes brought by 1952, there were very strong similarities in the basic structure of the political equilibrium. Kelley and Klein (1981) estimated that 10 years after the Revolution, inequality had returned to 1952 levels.

How can we understand an outcome like this? We believe that there are mechanisms that can generate persistence in the political equilibrium even when de jure and de facto power changes and can produce an iron law of oligarchy. The idea is quite simple. Initially in Bolivia institutions were structured to the benefit of traditional elites. A new elite emerged, spearheaded by the MNR. The MNR needed to win support of the campesinos and other urban groups. To do this they had to develop a political strategy, but the form that strategy took was highly influenced by the strategies being used by the traditional elite. The traditional elite were clientelistic, so it was optimal to use clientelism to compete with them. Similarly, the traditional elite ran a political system with few checks and balances. Would the MNR find it optimal to create a political system with checks and balances? Not necessarily. After all, though this might have appealed to citizens and garnered more support, it would also have been disadvantageous to them once they were in power. Hence there is a welldefined tradeoff. Indeed, the MNR were able to attain power and create highly imperfect political institutions that they were then able to undermine.

\subsubsection{General Lessons}

One might conclude from our discussion of the U.S. South that the real problem was the persistence of the elite and their resources. If only the North had implemented land reform and given the freed slaves their 50 acres and a mule, everything would have been different. The example of the Bolivian Revolution shows that the situation is more complex than this. In Bolivia the previous elite were expropriated and their power taken away, yet the new elite that emerged (the MNR) used strategies that were very similar to the old elite and that had the same impact on economic 
institutions. Thus there can be huge path dependence in political equilibria, even when de jure and de facto power changes hands from one group to another. This implies that, for reformers, a policy of changing political institutions and trying simultaneously to undermine the de facto power of incumbents may not work. In order to reform Iraq it is not sufficient to introduce democracy and undermine the Ba'ath Party. Instead, reformers must change the incentives of new elites and decouple their choices from those of the previous elites.

\subsubsection{Fighting Fire with Fire}

A related phenomena to what happened in Bolivia, but that seems to involve different mechanisms, arises mostly in sub-Saharan Africa. Many African countries have experienced changes in the identity of elites and groups in power, but the new leaders seem to be as bad as the old. Most strikingly this happened with the transition from colonial authority. After suffering under King Leopold and then the Belgian colonial state, the Congolese were faced with Patrice Lumumba, Joseph Mobutu, and Laurent Kabila. Is this just a coincidence? Similar transitions occurred in many African countries. After the Cocoa farmers in Ghana had protested against the policies of the British authorities, they were exploited even more vigorously by the government of Kwame Nkrumah. Other salient examples in British colonies are Siaka Stevens in Sierra Leone and perhaps the transition from Ian Smith to Robert Mugabe in Zimbabwe. Elsewhere on the continent the transition from Haile Selassia to Mengistu Haile Mariam in the 1970s is yet another example (see Meredith, 2005, on the extraordinary extent to which Mengistu ended up behaving like Haile Selassie). Transitions from one bad leader to another occurred not just at the time of decolonization, but also subsequently. In Zambia, for instance, the long struggle to remove Kenneth Kaunda and his United National Independence Party from power was headed by Frederick Chiluba and the Movement for Multiparty Democracy (MMD). Chiluba was elected president in 1991 after 27 years of UNIP rule. Though Chiluba introduced economic reforms, he also engaged in massive corruption.

The succession of bad leaders seems to be another example of the iron law of oligarchy. On the surface of it there appears to be change and often IFIs and foreign governments rush in to give aid and support to the new regime, only to become disillusioned with the lack of real change. There may be very good reasons for this phenomenon, however (Acemoglu and Robinson, 2007). Consider a situation where a society has a very predatory ruler or ruling clique that is willing to use repression and violence and bend all the rules to stay in power. How can citizens remove such a ruler? To get rid of it, it may be necessary to "fight fire with fire" and support a challenger who can be as unscrupulous as the incumbent regime. Think 
perhaps of the difference between supporting Mahatma Gandhi or Nelson Mandela. Gandhi was obviously a highly principled leader who, had he attained office, would have had the public interest at heart. It turned out that this was also true of Nelson Mandela, but this must have been much less clear in the period before he attained office. In the 1960s Mandela was prepared to be tough and he played an important role in the formation of Umkhonto we Sizwe, the armed wing of the African National Congress. Who would citizens back, Gandhi or Mandela? A Mandela is attractive because he has a much bigger chance of removing the Apartheid state from power, yet when he wins will he be as bad? Gandhi was clearly better than British colonialism, yet he had a much smaller chance of winning. So there is a well defined trade-off here. In African countries, where it is easy to break laws and there are few checks and balances, it may be relatively attractive for citizens to fight fire with fire. Yet doing this runs the risk of replacing one bad leader with another and not experiencing any improvement in the economic environment.

\subsubsection{General Lessons}

When citizens decide to fight fire with fire what can reformers do? The mechanism at work here is different from the one we hypothesized for Bolivia. There the initial strategy of the incumbent elite influenced the strategy of a new elite. Here, however, it is the citizens who make the most important decisions and this generates different implications. Again, direct reform of economic institutions is unlikely to be very useful and this mechanism applies in environments where political institutions probably face few constraints on the behavior of politicians. Nevertheless, this may be a case where external intervention to remove bad rulers would imply that citizens no longer need to support unscrupulous opponents to generate change. Some potential lessons could therefore be drawn from the recent experience of Sierra Leone, where the strong intervention of British soldiers in 2000 seems to have played an important role is destroying the power of various rebel movements and precipitating the movement of the country back to democracy and some stability. Now it may no longer be necessary for the citizens of Sierra Leone to fight fire with fire, as perhaps they did in 1967 when they put Siaka Stevens in power. The case of Sierra Leone, however, suggests how incomplete our understanding of dysfunctional political equilibria is. In the recent presidential election of September 2007 the people voted back into power the All People's Congress Party, the political machine built by Stevens that he and the ruling clique used as a basis to rule and loot the country for two decades before the onset of the civil war. 


\section{Successful Reform}

In the last section we used our framework to explain why reform is so difficult and why patterns of relative economic performance are so persistent over time. Nevertheless, countries do reform their institutions and move onto different development paths. Obvious examples that come to mind from the post-World War II development experience include Taiwan, China in the late 1950s; Singapore, the Republic of Korea, and Botswana in the 1960s; and Chile, Mauritius, and China in the 1970s. There have been important historical episodes of reform as well. As we noted earlier, Britain underwent an important process of institutional change in the seventeenth century, and again in the nineteenth century when it expanded democratic rights and began to invest more systematically in education. Obviously some of these instances of institutional transition took place under democracy, as in Botswana and Mauritius, while some took place under authoritarian regimes. Some countries, such as Spain, experienced institutional reforms under authoritarianism in the 1960s and democracy in the 1980s.

Earlier in the paper we described what drove this process of change in Britain. In particular we argued that there were changes in economic opportunities, which changed both interests and the balance of de facto power in society, which in turn destabilized the initial absolutist equilibrium. This led to a process of cumulative change in political and economic institutions. This did not end with the Glorious Revolution but extended to the Reform Acts of the nineteenth century and many other subsequent changes in economic institutions. All of these other examples of successful reform can be described within our framework. Let us consider just one example, Botswana.

As is well known, Botswana, a small, tropical, landlocked country in sub-Saharan Africa has had the fastest average rate of economic growth in the world in the last 35 years. So what explains Botswana's success? At a proximate level Botswana has been aided by large quantities of diamonds, yet in general natural resources are not associated with successful economic outcomes in Africa. It has also had very good macroeconomic and microeconomic policies and ranks at the same level as Western European countries in terms of indices of governance and corruption (Parsons and Robinson, 2006). The argument of Acemoglu, Johnson, and Robinson (2003) and Parsons and Robinson (2006) is that Botswana's success is precisely because of its economic and political institutions. Botswana benefited immensely from having indigenous political institutions that put constraints on Tswana chiefs and political elites, and in the nineteenth century the Tswana tribes engaged in a quite successful process of defensive modernization that strengthened these institutions. 
Significantly, these institutions were not undone by the impact of colonialism, which was very marginal in the country. Thus at independence Bostwana emerged with political institutions that placed checks and balances on political elites. This was important for the security of property rights and governance and it is an almost unique phenomenon in Africa. In consequence economic institutions were good. Economic institutions were also good because the Tswana chiefs and elite were heavily invested in the main economic sector at independence, which was ranching. Hence, as in Britain after the Glorious Revolution, political elites had a vested interest in economic institutions that were socially desirable. In addition, other historical factors were certainly important, such as the fact that the modern nation of Botswana had a certain coherence that other African natures lacked. Much of the apparent homogeneity of Botswana is actually an outcome of the process of state formation, rather than a prerequisite for it (see Leith, 2005, on this).

Botswana did well because its political equilibrium facilitated good economic institutions in rather a similar way to the situation in late seventeenth century Britain. Indeed we can even understand this in the same way in terms of the interaction of de jure political constraints and economic interests. The agenda ahead is to understand better how such an equilibrium can be created elsewhere in Africa.

\section{Conclusions}

There are several key conclusions that we believe can be drawn from this analysis. The main determinants of cross-country differences in income per capita are differences in economic institutions. Though institutions often persist for long periods of time and have unintended consequences, differences in institutions across countries primarily reflect the outcome of different collective choices. Different collective choices reflect differences in political institutions and different distributions of political power. As a result, understanding underdevelopment implies understanding why different countries get stuck in political equilibria that result in bad economic institutions. Solving the problem of development entails understanding what instruments can be used to push a society from a bad to a good political equilibrium. Unfortunately, this is far beyond what we understand at the moment and, as yet, we do not have a deep enough comprehension of the forces that lead to good or bad political equilibria. There are some robust patterns in the cross-national data and some obvious things that can be said. For instance, in the case of Africa, promoting democracy and accountability and checks and balances will almost certainly lead to better economic policies and institutions. 
Though it is true that there have been developmental authoritarian regimes in East Asia, there has never been one in sub-Saharan Africa, so creating one seems a good option neither from the point of view of political freedom nor economic growth. Nevertheless, there are clear pitfalls in promoting both good economic and political institutions and we cannot say that improvements in accountability, for instance, will push African countries onto much better growth paths. In this paper we have focused on these pitfalls and showed that they demonstrate how cautious one must be in promoting reforms. For instance, one cannot necessarily change the political equilibrium by introducing democracy. These pitfalls also illustrate why, for example, so many people in Latin America have been disappointed by the results of the apparent application of the Washington Consensus. It is not that these reforms would not be good, other things being equal; it is just that other things are not equal. Reform in one area leads other areas to become unreformed. Our analysis poses challenging problems for those who would wish to solve the problem of development and poverty. Nevertheless, experience strongly suggests that it is difficult to solve these problems and we believe that the main reasons for this are the forces we have outlined in this paper. Better development policy will only come when we recognize this and understand these forces better.

Nevertheless, countries do reform their institutions and move from situations of stagnation to rapid growth. We have argued that this is because of changes in the political equilibrium. It can hardly be denied, for example, that the rapid take-off of growth in China after 1978 was a result of policy and institutional reforms. These were a direct result of the defeat of the "Gang of Four" and a dramatic shift in those who controlled the Communist Party. Growth did not occur because the culture of the Chinese changed, or because some geographical constraint was lifted. Growth also did not occur because previously the Chinese were mistaken about the correct form of policy. They did not suddenly discover what to do. Rather, growth occurred because the political equilibrium changed in a way that gave more power to those who wanted to push through reforms. Said in this way our analysis is an optimistic one. The institutional approach opens the promise that if we can understand the determinants of political equilibria then we can really design interventions that make poor societies prosperous. There is no intrinsic reason why Mali is poor and it is possible to make its citizens rich. 


\section{References}

Acemoglu, D. (2008). Oligarchic versus Democratic Societies. Journal of the European Economic Association, 6 (1), 1-44. doi:10.1162/JEEA.2008.6.1.1

Acemoglu, D., \& Robinson, J.A. (2000). Why Did the West Extend the Franchise? Democracy, Inequality and Growth in Historical Perspective. Quarterly Journal of Economics, 115 (4), 1167-1199. doi:10.1162/003355300555042

Acemoglu, D., \& Robinson, J.A. (2006a). Economic Origins of Dictatorship and Democracy. New York: Cambridge University Press. doi:10.1111/j.1467-8276.2009.01276_3.x

Acemoglu, D., \& Robinson, J.A. (2006b). Economic Backwardness in Political Perspective. American Political Science Review, 100 (1), 115-131. doi:10.1017/S0003055406062046

Acemoglu, D., \& Robinson, J.A. (2006c). De Facto Political Power and Institutional Persistence. American Economic Review, 96 (2), 325-330. doi: $10.1257 / 000282806777212549$

Acemoglu, D., \& Robinson, J.A. (2008). Persistence of Power, Elites and Institutions. American Economic Review, 98 (1), 267-293. doi:10.1257/aer.98.1.267

Acemoglu, D., \& Robinson, J.A. (2007). A Model of the Iron Law of Oligarchy. Work in progress.

Acemoglu, D., Johnson, S., \& Robinson, J.A. (2001). The Colonial Origins of Comparative Development: an Empirical Investigation. American Economic Review, 91 (5), 1369-1401. doi:10.1257/aer.91.5.1369

Acemoglu, D., Johnson, S., \& Robinson, J.A.(2002). Reversal of Fortune: Geography and Institutions in the Making of the Modern World Income Distribution. Quarterly Journal of Economics, 117 (4): 1231-1294. doi:10.1162/003355302320935025

Acemoglu, D., Johnson, S., \& Robinson, J.A. (2003). An African Success: Botswana. In: Rodrik, D. (ed.) In Search of Prosperity: Analytic Narratives on Economic Growth. Princeton: Princeton University Press.

Acemoglu, D., Johnson, S., \& Robinson, J.A. (2005a). The Rise of Europe: Atlantic Trade, Institutional Change and Economic Growth. American Economic Review, 95 (3), 546-579. doi:10.1257/0002828054201305

Acemoglu, D., Johnson, S., \& Robinson, J.A. (2005b). Institutions as the Fundamental Cause of Long-Run Growth. In: Aghion, P., \& Durlauf, S.N. (eds.). Handbook of Economic Growth, Vol. 1, Part 1, Elsevier: 385472. doi:10.1016/S1574-0684(05)01006-3 
Acemoglu, D., Johnson, S., Robinson, J.A., \& Thaicharoen, Y. (2003). Institutional Causes, Macroeconomic Symptoms. Journal of Monetary Economics, 50 (1), 49-123. doi:10.1016/S0304-3932(02)00208-8

Bateman, F., \& Weiss, T. (1981). A Deplorable Scarcity: The Failure of Industrialization in the Slave Economy. Chapel Hill, University of North Carolina Press.

Bates, R.H. (1981). Markets and States in Tropical Africa. Berkeley: University of California Press.

Coate, S.T., \& Morris, S.E. (1995).On the Design of Transfers to Special Interests. Journal of Political Economy, 103 (6), 1210-1235. doi:10.1086/601449

Coate, S.T., \& Morris, S.E. (2005). Policy Conditionality. In: Ranis, G., \& Vreeland, J.R. (eds.). Globalization and the Nation State: The Impact of the IMF and World Bank. New York: Routledge.

Cobb, J.C. (1984). Industrialization and Southern Society, 1877-1984. Lexington: University Press of Kentucky.

Curtin, P.D. (1964). The Image of Africa. Madison: University of Wisconsin Press.

Djankov, S., LaPorta, R., Lopez-de-Silanes, F., \& Shleifer, A. (2002). The Regulation of Entry. Quarterly Journal of Economics, 117 (1), 1-37. doi:10.1162/003355302753399436

Du Bois, W.E.B. (1903). The Souls of Black Folk. New York: A.C. McClurg \& Company.

Gibson, E.L. (1997). The Populist Road to Market Reform: Policy and Electoral Coalitions in Mexico and Argentina. World Politics, 49 (3), 339370. doi:10.1353/wp.1997.0011

Heath, D. (1972). New Patrons for Old: Changing Patron-Client Relationships in the Bolivian Yungas. In: Strickton, A., \& Greenfield, S. (eds.). Structure and Process in Latin America. Albuquerque: University of New Mexico Press.

Herbst, J.I. (1990). The Structural Adjustment of Politics in Africa. World Development, 18 (7), 949-958. doi:10.1016/0305-750X(90)90078-C

Hughes, C. (2003). The Political Economy of Cambodia's Transition, 19912001. New York: Routledge. doi:10.4324/9780203221754

Kelley, J., \& Klein, H.S. (1981). Revolution and the Rebirth of Inequality: A Theory Applied to the National Revolution in Bolivia. Berkeley: University of California Press.

Key, V.O. Jr. (1949). Southern politics in State and Nation. New York: A.A. Knopf. doi:10.1177/106591295000300133 
Knack, S., \& Keefer, P. (1995). Institutions and Economic Performance: Cross-Country Tests using Alternative Measures. Economics and Politics, 7 (3), 207-227. doi:10.1111/j.1468-0343.1995.tb00111.x

Kousser, J.M.(1974). The Shaping of Southern Politics: Suffrage Restriction and the Establishment of the One-Party South, 1880-1910. New Haven: Yale University Press.

Leith, J.C. (2005). Why Botswana Prospered. Montreal: McGill-Queen's University Press.

Levitsky, S.(2003). Transforming Labor-Based Parties in Latin America. Argentine Peronism in Comparative Perspective. New York: Cambridge University Press. doi:10.1017/CBO9780511615641

Lindert, P.H. (2004). Growing Public: Social Spending and Economic Growth since the 18th Century. New York: Cambridge University Press. doi:10.1017/CBO9780511510717

Margo, R.A. (1990). Race and Schooling in the South, 1880-1950: an Economic History. Chicago: University of Chicago Press.

Mauro, P. (1995). Corruption and Growth. Quarterly Journal of Economics, 110 (3), 681-712. doi:10.2307/2946696

Meredith, M. (2005). The Fate of Africa: From the Hopes of Freedom to the Heart of Despair: a History of Fifty Years of Independence. New York: Public Affairs.

Michels, R. (1962). Political Parties. New York: The Free Press.

Mosca, G. (1939). The Ruling Class. New York: McGraw-Hill.

North, D.C. (1981). Structure and Change in Economic History. New York: W.W. Norton \& Co.

North, D. C. (1990). Institutional Change, and Economic Performance. New York: Cambridge University Press.

Pareto, V. (1968). The Rise and Fall of the Elites. New York: Arno Press.

Parsons, Q.N., \& Robinson, J.A. (2006). State Formation and Governance in Botswana. Journal of African Economies, 15 (1), 100-140. doi:10.1093/jae/ejk007

Ransom, R.L., \& Sutch, R. (2001).One Kind of Freedom: The Economic Consequences of Emancipation. New York: Cambridge University Press. 2nd Edition.

Reno, W. (1998).Warlord Politics and African States. Boulder: Lynne Rienner Publishers.

Roberts, K.M. (1995). Neoliberalism and the Transformation of Populism in Latin America. World Politics, 48 (1), 82-116.

doi:10.1353/wp.1995.0004 
Roberts, K.M., \& Arce, M. (1998). Neoliberalism and Lower Class Voting Behavior in Peru. Comparative Political Studies, 31 (2), 217-246. doi:10.1177/0010414098031002004

Rodrik, D. (2006). Goodbye Washington Consensus, Hello Washington Confusion? A Review of the World Bank's Economic Growth in the 1990s: Learning from a Decade of Reform. Journal of Economic Literature, 44 (4): 973-987. doi:10.1257/jel.44.4.973

Schulman, B.J. (1994). From Cotton Belt to Sunbelt: Federal Policy, Economic Development and the Transformation of the South, 1938-1980. Durham: Duke University Press.

Stigler, G. (1971). The Economic Theory of Regulation. Bell Journal of Economics and Management Science, 2 (1), 3-21. doi:10.2307/3003160

Stigler, G. (1982). Economist and Public Policy. Regulation, 6, 13-17.

Tawney, R.H. (1941). The Rise of the Gentry, 1558-1640. Economic History Review 11 (1), 1-38. doi:10.2307/2590708

van de Walle, N. (1993). The Politics of Nonreform in the Cameroon. In Callaghy, T.M, \& J. Ravenhill (eds.), Responses to Africa's Economic Decline. New York: Columbia University Press.

van de Walle, N. (2000). The Politics of Permanent Crisis: Managing African Economies, 1979-1999. New York: Cambridge University Press.

Weyland, K.G. (1998). Swallowing the Bitter Pill: Sources of Popular Support for Neoliberal Reform. Comparative Political Studies 31 (5), 53968. doi:10.1177/0010414098031005001

Weyland, K.G. (2002). The Politics of Market Reform in Fragile Democracies: Argentina, Brazil, Peru, and Venezuela. Princeton: Princeton University Press.

Wiener, J.M. (1978). Social Origins of the New South: Alabama, 1860-1885. Baton Rouge: Louisiana State University Press.

Woodward, C.V. (1951). Origins of the New South, 1877-1913. Baton Rouge: Louisiana State University Press.

Woodward, C.V. (1955). The Strange Career of Jim Crow. New York: Oxford University Press.

Wright, G. (1986). Old South, New South. New York: Basic Books. 